\title{
Optimization of Biosorption Conditions of Hexavalent Chromium by Aspergillus niger and Spicaria silvatica Mycelial Mats, Using Taguchi Orthogonal Array
}

\author{
${ }^{1}$ N.A. Tharwat, ${ }^{1}$ T.M. A. Abdel-Rahman, ${ }^{2}$ A.H Mostafa and \\ ${ }^{2}$ M.A. Ahmed \\ ${ }^{1}$ Botany department, Faculty of Science, Cairo University and \\ ${ }^{2}$ National Center for Research on Housing and Building, \\ Giza, Egypt.
}

\begin{abstract}
$\mathrm{N}$ ORDER to maximize the biosorption efficiency, eighteen experiments were designed to investigate the potentialities of fungal biomass as a resistant and cost effective $\mathrm{Cr}^{+6}$ biosorbent. The influences of individual parameters as well as the interaction between them were studied using Taguchi statistical design. A group of statistical analysis that can define the relationships between the responses of independent variables were carried out. In the current study, it was detected that the biosorbed $\mathrm{Cr}^{+6}$ by A. niger and $S$. silvatica varied greatly among the 18 media used indicating the importance of optimization experiments in bioprocesses. In case of $A$. niger the ANOVA analysis of variance revealed that temperature, mycelium status, $\mathrm{NaNO}_{3}$ and agitation were the most significant factors influencing the $\mathrm{Cr}^{+6}$ biosorption. In $S$. silvatica, temperature, mycelium status, agitation and $\mathrm{MgSO}_{4} 7 \mathrm{H}_{2} \mathrm{O}$ were the highly significant variables influencing $\mathrm{Cr}^{+6}$ biosorption. The design detected that the experimental values of biosorbed $\mathrm{Cr}^{+6}$ were in reasonable agreement with the predicted values and the model was significant. The optimized predicted medium from the software design for $\mathrm{Cr}^{+6}$ biosorption by A. niger and S. silvatica was (A) dead mycelium (B) sucrose $\left(15 \mathrm{gl}^{-1}\right) \quad$ (C) $\mathrm{NaNO}_{3}\left(1.5 \mathrm{gl}^{-1}\right)$ (D) $\mathrm{MgSO}_{4} 7 \mathrm{H}_{2} \mathrm{O} \quad\left(0.1 \mathrm{gl}^{-1}\right)$

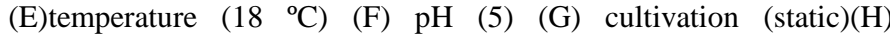
incubation period (5days).
\end{abstract}

Keywords: Biosorption, Hexavalent chromium, Aspergillus niger, Spicaria silvatica, Tannery pollution.

The tanning industry forms the backbone of the Egyptian leather industry. The total numbers of tanneries in Egypt are more than 300, of which more than $85 \%$ adopt the chromium tanning process (Ibrahim. and Shalaby, 1991) because of its processing speed, low costs, and light color of leather and greater stability of the resulting leather. Tannery effluent containing chromium is one of the most recognized problems in leather industry. Tanning process using chromium compounds is the most common methods for processing of hides (Sreeram, and Ramasami, 2003). 
Biosorption is such a technology for treatment of industrial wastewater by interaction with live or dead biological matter and is the most practical and widely used approach for bioremediation of toxic metals and radio nuclides (Volesky, 1990). Biosorption is also defined as a process that utilizes inexpensive dead biomass to sequester toxic heavy metals and to remove contaminants from industrial effluents (Ting et al., 1991 and Singh et al. 1998). The use of biological materials for heavy metal removal and recovery technologies had gained important credibility, because of the good performance, low cost of this complex material and could be considered as an eco-friendly complementary device to the existing high cost technologies. The natural affinity of biological compounds for metallic elements could contribute to economically purifying heavily metal-loaded wastewater (Ferraz and Teixera, 1999). Many microorganisms had been examined for their biosorptive properties. Fungi, Yeasts, bacteria, and algae had been identified as superior candidates for bioremediation owing to their ability to sequester cationic and anionic metallic species from their aqueous environment (Luef et al. 1991; Mclean et al. 1994; Tobin et al. 1994; Volesky and Holan, 1995 and Volesky and May-Philips, 1995 and Anaemene, 2012). Most studies of biosorption for metal removal had involved the use of either laboratory-grown microorganism or waste biomass generated by the pharmacology and food processing industries or wastewater treatment units (Rao et al. 1993). Both living and dead biomass could be used to remove metals, but maintaining a viable biomass during metal adsorption was difficult, because it required a continuous supply of nutrients and avoidance of metal toxicity to the microorganisms (Spinti et al. 1995). Use of dead biomass could avoid these problems.

The bioadsorptive capacity of the heat-inactivated cells might be greater, equivalent or less than that of living cell. However, the use of heat inactivated biomass in industrial application might offer some advantages over living cells, such as less sensitive to heavy metal ions concentration and adverse operating conditions (i.e., $\mathrm{pH}$ and temperature) (Gadd and White, 1989 and Kapoor et al. 1999). Also dead biomass could be regenerated and reused for many cycles. However, the use of dead biomass in powdered form had some problems, such as; difficulty in the separation of biomass after adsorption, mass loss after regeneration, low strength and small particle size, which made it difficult to use in column applications (Kapoor and Viraraghavan, 1998 and Yan and Viraraghavan, 2000). Dead biomass could be immobilized in a granular or polymeric matrix to improve the mechanical strength of the biosorbent. The immobilized biomass was ideal for use in a conventional ion-exchange column or adsorption column (Volesky, 1990).

The traditional "one factor-at-a time" technique used for optimizing a multivariable system is not only time waste, but also require carrying out a number of experiments to determine the optimum levels when the interaction is significant. Statistical optimization design could eliminate these drawbacks by 
optimizing all the affecting parameters collectively (Doehlert, 1970). Response service methodologies (RSM) involve four major steps: i) performing the statistically designed experiments, ii) estimating the coefficient in a mathematical model, iii) predicting its response and iv) checking the adequacy of the model (Dasu and Panda, 2000; Reddey et al. 2008). Statistically designed experiments minimize the error in determining the effect of parameters in an economical manner (Sharma and Satyanarayan, 2006).

Process optimization plays a vital role in industrial production process in which even small improvement would be decisive for commercial success. In any bioprocess, the small improvement in productivity of any metabolite such as enzymes, hormones, toxins would be achieved through manipulation of the nutritional and physical parameters (Reddy et al. 2008).

The objective of this work is to optimize the biosorption conditions of hexavalent chromium by Aspergillus niger and Spicaria silvatica mycelial mats, using Taguchi Orthogonal Array (Prasad et al., 2005).

\section{Material and Methods}

\section{Test organisms}

Two fungal species isolated from $\mathrm{Cr}^{3+}$ and $\mathrm{Cr}^{6+}$ polluted soil with tannery water (Tharwat et al., 2013).

\section{Estimation of adsorbed and absorbed $\mathrm{Cr}^{+6}$ by fungal species}

Definite weight of fresh mycelia were washed 3 times with 1.0 M HCL and the washes were pooled and used for determination of the adsorbed chromium on the surface of fungal mycelia. The absorbed chromium inside mycelia was determined in dry biomass after grounding with mortar and pestle. $0.1 \mathrm{~g}$ of crushed mycelia was digested in $1 \mathrm{ml}$ of concentrated nitric acid and heated in boiling water bath for $1 \mathrm{hr}$. After cooling the digest was diluted with an appropriate volume of $\mathrm{ddH}_{2} \mathrm{O}$. Chromium content of diluted mycelial extracts and culture filtrates were determined spectrophotometricaly after complication of the metal ions with 1,5- diphenyle carbazide at $540 \mathrm{~nm}$ (Bartlett and James., 1996).

Optimization of the biosorption conditions of hexa valent chromium by Aspergillus niger and Spicaria silvatica mycelial mats

The size of experimentation was represented by symbolic arrays L18 which indicates 18 experimental trails). Seven indicates 18 experimental trails). 5) factors have been assigned with three levels $\left(7^{3}\right)$ except mycelium was assigned with 2 levels $\left(1^{2}\right)$ with a layout of L18 $\left(1^{2} \times 7^{3}\right)$ (Table 2). 
TABLE 1. Selected variables and their assigned levels for optimization process using Taguchi software design expert 8 was used in this optimization system (Prasad et al., 2005).

\begin{tabular}{|l|c|c|c|}
\hline \multicolumn{1}{|c|}{ variables } & Level 1 & Level 2 & Level 3 \\
\hline (A)Mycelium & Dead (250mg \%) & Alive (2disc \%) & --- \\
$($ B) Sucrose (g/L) & 15 & 20 & 30 \\
$($ C)Sodium nitrate (g/L) & 1.5 & 3 & 4.5 \\
$($ D) MgSO4 7H2O (g/L) & 0.1 & 0.5 & 1 \\
$\left(\right.$ E) Temperature ( ${ }^{\mathbf{C}}$ ) & 18 & 28 & 38 \\
$($ F) pH & 5 & 7 & 9 \\
$($ G) Agitation(rpm) & Static & 120 & 200 \\
$($ H) Incubation(day) & 5 & 7 & 10 \\
\hline
\end{tabular}

TABLE 2. Fractional factorial design of L-18 $\left(1^{2} X 7^{3}\right)$ orthogonal array used for optimization process.

\begin{tabular}{|c|l|l|l|l|l|l|l|l|}
\hline \multirow{2}{*}{$\begin{array}{c}\text { Experiments } \\
\text { No. }\end{array}$} & \multicolumn{10}{|c|}{ Designed Experiments } \\
\cline { 2 - 8 } 1 & 1 & 2 & 3 & 4 & 5 & 6 & 7 & 8 \\
2 & 1 & 1 & 1 & 1 & 1 & 1 & 1 & 1 \\
3 & 1 & 1 & 2 & 2 & 2 & 2 & 2 & 2 \\
4 & 1 & 2 & 1 & 1 & 2 & 2 & 3 & 3 \\
5 & 1 & 2 & 2 & 2 & 3 & 3 & 1 & 1 \\
6 & 1 & 2 & 3 & 3 & 1 & 1 & 2 & 2 \\
7 & 1 & 3 & 1 & 2 & 1 & 3 & 2 & 2 \\
8 & 1 & 3 & 2 & 3 & 2 & 1 & 3 & 1 \\
9 & 1 & 3 & 3 & 1 & 3 & 2 & 1 & 2 \\
10 & 2 & 1 & 3 & 3 & 3 & 2 & 2 & 1 \\
11 & 2 & 1 & 1 & 1 & 1 & 3 & 3 & 2 \\
12 & 2 & 1 & 2 & 2 & 2 & 1 & 1 & 3 \\
13 & 2 & 2 & 1 & 2 & 3 & 1 & 3 & 2 \\
14 & 2 & 2 & 2 & 3 & 1 & 2 & 1 & 3 \\
15 & 2 & 2 & 3 & 1 & 2 & 3 & 2 & 1 \\
16 & 2 & 3 & 1 & 3 & 2 & 3 & 1 & 2 \\
17 & 2 & 3 & 2 & 1 & 3 & 1 & 2 & 3 \\
18 & 2 & 3 & 3 & 2 & 1 & 2 & 3 & 1 \\
\hline
\end{tabular}

Eighteen media were designed. The composition of them was recorded in Table 3. 
TABLE 3. Composition of The 18 designed media from the interactions of 3 levels of the eight factors.

\begin{tabular}{|c|c|c|c|c|c|c|c|c|}
\hline Media & $\begin{array}{c}\text { Mycelium } \\
\text { (A) } \\
\text { mg\% }\end{array}$ & $\begin{array}{c}\text { Sucrose } \\
\text { (B) } \\
\text { g/L }\end{array}$ & $\begin{array}{c}\mathrm{NaNO}_{3} \\
(\mathrm{C}) \\
\mathrm{g} / \mathrm{L}\end{array}$ & $\begin{array}{c}\text { MgSO } \\
4 \\
7 \mathrm{H} 2 \mathrm{O} \\
\text { (D) }\end{array}$ & $\begin{array}{c}\text { Temp } \\
\text { (E) } \\
{ }^{\circ} \mathbf{C}\end{array}$ & $\begin{array}{l}\text { pH } \\
\text { (F) }\end{array}$ & $\begin{array}{c}\text { Agitation } \\
\text { (G) } \\
\text { Rpm }\end{array}$ & $\begin{array}{c}\text { Incubation } \\
\text { (H) } \\
\text { Days }\end{array}$ \\
\hline 1 & Dead & 15 & 1.5 & 0.1 & 18 & 5 & Static & 5 \\
\hline 2 & Dead & 15 & 3 & 0.5 & 28 & 7 & 120 & 7 \\
\hline 3 & Dead & 15 & 4.5 & 1 & 38 & 9 & 200 & 10 \\
\hline 4 & Dead & 20 & 1.5 & 0.1 & 28 & 7 & 200 & 10 \\
\hline 5 & Dead & 20 & 3 & 0.5 & 38 & 9 & Static & 5 \\
\hline 6 & Dead & 20 & 4.5 & 1 & 18 & 5 & 120 & 7 \\
\hline 7 & Dead & 30 & 1.5 & 0.5 & 18 & 9 & 120 & 7 \\
\hline 8 & Dead & 30 & 3 & 1 & 28 & 5 & 200 & 5 \\
\hline 9 & Dead & 30 & 4.5 & 0.1 & 38 & 7 & Static & 7 \\
\hline 10 & Alive & 15 & 4.5 & 1 & 38 & 7 & 120 & 5 \\
\hline 11 & Alive & 15 & 1.5 & 0.1 & 18 & 9 & 200 & 7 \\
\hline 12 & Alive & 15 & 3 & 0.5 & 28 & 5 & Static & 10 \\
\hline 13 & Alive & 20 & 1.5 & 0.5 & 38 & 5 & 200 & 7 \\
\hline 14 & Alive & 20 & 3 & 1 & 18 & 7 & Static & 10 \\
\hline 15 & Alive & 20 & 4.5 & 0.1 & 28 & 9 & 120 & 5 \\
\hline 16 & Alive & 30 & 1.5 & 1 & 28 & 9 & Static & 7 \\
\hline 17 & Alive & 30 & 3 & 0.1 & 28 & 5 & 120 & 10 \\
\hline 18 & Alive & 30 & 4.5 & 0.5 & 18 & 7 & 200 & 5 \\
\hline
\end{tabular}

Analysis of experimental data and prediction of performance

The obtained experimental results were fitted in Taguchi (Prasad et al., 2005) software (Design-Expert 8- or-Qualitek4) to analyze the influences of individual and interactive factors. ANOVA used to determine the optimum culture conditions for biosorption and to detect the contribution of each selected factor for biosorption activity of fungi .The Qualitek-4 software was equipped to use L4 to L-64 arrays along with selection of 2 to 63 factors with two, three and four levels to each factor. The automatic design option allows qualitek-4 to select the array used and assign factors to the appropriate flasks. Software operation for optimization was performed at (bigger is better) performance characteristics for all the cases.

\section{Results and Discussion}

The data in Table 4 indicated that the experimental actual values of the biosorbed $\mathrm{Cr}^{+6}$ by $A$. niger and $S$. silvatica assessed significant variation among the 18 designed media. It varies from 2.80 to $45.20 \mu \mathrm{g} \mathrm{ml}^{-1}$ in A. niger and from 2.20 to $40 \mu \mathrm{g} \mathrm{ml}^{-1}$ in $S$. silvatica. This indicated the importance of cultural optimization in metal biosorption by the microorganisms. The optimum medium for A. niger was medium (2) containing (dead mycelium, sucrose, $15 \mathrm{~g} / \mathrm{l}$, 
NaNO3, $3 \mathrm{~g} / \mathrm{l}, \quad \mathrm{Mg} \mathrm{SO} 47 \mathrm{H}_{2} \mathrm{O}, 0.5 \mathrm{~g} / \mathrm{l}$, temperature $28{ }^{\circ} \mathrm{C}, \mathrm{pH} 7$, agitation speed $120 \mathrm{rpm}$, incubation period 7 days).

while the optimum medium for Cr6+ biosorption by S. silvatica was medium (3) containing (dead mycelium, sucrose, $15 \mathrm{~g} / \mathrm{l}, \mathrm{NaNO} 3,4.5 \mathrm{~g} / \mathrm{l}, \mathrm{Mg} \mathrm{SO} 47 \mathrm{H}_{2} \mathrm{O}, 1.0$ $\mathrm{g} / \mathrm{l}$, temperature $38^{\circ} \mathrm{C}, \mathrm{pH}$ 9, agitation speed $200 \mathrm{rpm}$, incubation period 10 days).

TABLE 4. Optimization of biosorption conditions of hexavalent chromium (experimental values) by Aspergillus niger and Specaria silvatica mycelial mats using Taguchi Orthogonal Array (OAs) Design.

\begin{tabular}{|c|c|c|}
\hline Exp. no & Aspergillus niger & Spicaria silvatica \\
\hline & Biosorbed $\mathrm{Cr}^{+6}(\mu \mathrm{g} / \mathrm{ml})$ & Biosorbed Cr$^{+6}(\mu \mathrm{g} / \mathrm{ml})$ \\
\hline 1 & 5.2 & 5.6 \\
\hline 2 & 45.2 & 11.2 \\
\hline 3 & 40 & 34.2 \\
\hline 4 & 16.8 & 23 \\
\hline 5 & 30.4 & 5.8 \\
\hline 6 & 3.8 & 15 \\
\hline 7 & 13.2 & 8.2 \\
\hline 8 & 23.4 & 40 \\
\hline 9 & 6.2 & 20 \\
\hline 10 & 14 & 8.8 \\
\hline 11 & 2.8 & 2.2 \\
\hline 12 & 14.6 & 17.6 \\
\hline 13 & 13.4 & 3.2 \\
\hline 14 & 5.2 & 4.2 \\
\hline 15 & 3.2 & 6.8 \\
\hline 16 & 8.8 & 9.4 \\
\hline 17 & 40 & 16.2 \\
\hline 18 & 5.4 & 7 \\
\hline
\end{tabular}

The diagnostic case statistics of $\mathrm{Cr}^{+6}$ biosorption by A. niger and $S$. silvatica detected that the actual experimental values were in reasonable agreements with the predicted values in 11 of 18 media .The residual values, however, exceeded limits $\left(4 \mathrm{\mu gml}^{-1}\right)$ in 7 of 18 media which were of numbers $1,3,7,10,13,15$ and 16 in case of A. niger and 5,7,8,9,12,14\&15 in case of $S$. silvatica (Table 5).

From ANOVA analysis of variance (Table 6) the F-value of the source model is equal $15.24 \& 15.75$ for $A$. niger and S. silvatica, respectively. This implies that the source models are significant. Furthermore, the P-value of less than 0.05 indicates that the model variables are significant. In case of $A$. niger $\mathrm{NaNO}_{3}$ and temperature are the most significant variables affecting biosorption of $\mathrm{Cr}^{+6}$. Mycelium status, sucrose and agitation came next in significance. In case of $S$. silvatica, mycelium status, $\mathrm{NaNO}_{3}, \mathrm{MgSO}_{4} 7 \mathrm{H}_{2} \mathrm{O}$, temperature and agitation are highly significant variables in $\mathrm{Cr}^{+6}$ biosorption where the $\mathrm{P}$ values were less than 0.05 . 
TABLE 5. Diagnostic case statistics of chromium biosorption by $A$. niger and $S$.

\begin{tabular}{|c|c|c|c|c|c|c|c|c|}
\hline & \multicolumn{2}{|c|}{$\begin{array}{l}\text { Actual value } \\
\left(\mu \mathrm{g} \mathrm{ml}^{-1}\right)\end{array}$} & \multicolumn{2}{|c|}{$\begin{array}{l}\text { Predicted value } \\
\quad\left(\mu \mathrm{g} \mathrm{ml}^{-1}\right)\end{array}$} & \multicolumn{2}{|c|}{$\begin{array}{l}\text { Residual value } \\
\left(\mu \mathrm{g} \mathrm{ml}^{-1}\right)\end{array}$} & \multicolumn{2}{|c|}{$\begin{array}{c}\text { Student } \cdot s \\
\text { (t-test) }\end{array}$} \\
\hline & A. niger & $\begin{array}{c}\text { S. } \\
\text { silvatica }\end{array}$ & A. niger & $\begin{array}{c}S . \\
\text { silvatica }\end{array}$ & $\begin{array}{c}\text { A. } \\
\text { niger }\end{array}$ & $\begin{array}{c}S . \\
\text { silvatica }\end{array}$ & $\begin{array}{c}\text { A. } \\
\text { niger }\end{array}$ & $\begin{array}{c}S . \\
\text { silvatica }\end{array}$ \\
\hline 1 & 5.20 & 5.6 & 12.08 & 4.10 & $-6.88 *$ & 1.50 & -2.86 & 0.28 \\
\hline 2 & 45.20 & 11.20 & 42.91 & 12.20 & 3.29 & -1.00 & 1.210 & -0.459 \\
\hline 3 & 40.00 & 34.20 & 31.91 & 33.32 & $8.09 *$ & 0.88 & 2.14 & 0.193 \\
\hline 4 & 16.80 & 23.00 & 20.26 & 25.37 & -3.46 & -2.37 & -0.662 & -0.400 \\
\hline 5 & 30.40 & 5.80 & 27.30 & 10.77 & 3.10 & $-4.97 *$ & 0.423 & -0.877 \\
\hline 6 & 3.80 & 15.00 & 1.59 & 13.47 & 2.21 & 1.53 & 6.302 & 0.255 \\
\hline 7 & 13.20 & 6.20 & 9.35 & 1.24 & $5.85^{*}$ & $6.96^{*}$ & 1.524 & 1.242 \\
\hline 8 & 23.40 & 40.00 & 26.81 & 34.15 & -3.41 & $8.85^{*}$ & -1.496 & 1.184 \\
\hline 9 & 6.20 & 20.00 & 6.64 & 14.24 & -0.44 & $5.76^{*}$ & -0.154 & 1.037 \\
\hline 10 & 14.00 & 8.80 & 20.49 & 8.78 & $-6.49 *$ & 0.22 & -2.160 & 0.005 \\
\hline 11 & 2.80 & 2.20 & 1.24 & -0.43 & 1.56 & 2.63 & 0.262 & 0.824 \\
\hline 12 & 14.60 & 17.60 & 17.35 & 11.60 & -2.75 & $6.00 *$ & -0.300 & 1.034 \\
\hline 13 & 13.40 & 3.20 & 19.39 & 6.24 & $-5.99 *$ & -3.04 & -1.066 & -0.739 \\
\hline 14 & 5.20 & 40.20 & 9.16 & 12.87 & -3.96 & $-8.67 *$ & -0.602 & -1.771 \\
\hline 15 & 3.20 & 6.80 & 9.76 & 15.67 & $-6.59 *$ & $-8.87 *$ & -1.294 & -1.732 \\
\hline 16 & 8.80 & 8.80 & -3.13 & 8.78 & $10.93^{*}$ & 0.022 & 4.11 & 0.005 \\
\hline 17 & 40.00 & 16.20 & 38.27 & 14.84 & 1.73 & 1.36 & 0.364 & 0.227 \\
\hline 18 & 5.40 & 7.00 & 2. 18 & 10.94 & 3.22 & -3.94 & 0.537 & -0.679 \\
\hline
\end{tabular}

(*) Exceed limits.

TABLE 6. ANOVA analysis of variance for selected factorial model.

\begin{tabular}{|c|c|c|c|c|c|c|c|c|c|c|}
\hline \multirow{2}{*}{ Variables } & \multicolumn{2}{|c|}{\begin{tabular}{|c|} 
Sum of squares \\
$\left(\mathbf{R}^{2}\right)$
\end{tabular}} & \multicolumn{2}{|c|}{$\begin{array}{c}\text { Degree of } \\
\text { freedom }(\mathbf{d f})\end{array}$} & \multicolumn{2}{|c|}{ Mean square } & \multicolumn{2}{|c|}{ F value } & \multicolumn{2}{|c|}{$P$ value } \\
\hline & A. niger & $\begin{array}{c}\text { S. } \\
\text { silvatica }\end{array}$ & $\begin{array}{c}\text { A. } \\
\text { niger }\end{array}$ & $\begin{array}{c}\text { S. } \\
\text { silvatica }\end{array}$ & $\begin{array}{c}A . \\
\text { niger }\end{array}$ & $\begin{array}{c}\text { S. } \\
\text { silvatica }\end{array}$ & $\begin{array}{c}\text { A. } \\
\text { niger }\end{array}$ & $\begin{array}{c}S . \\
\text { silvatica }\end{array}$ & $\begin{array}{c}A . \\
\text { niger }\end{array}$ & $\begin{array}{c}S . \\
\text { silvatica }\end{array}$ \\
\hline $\begin{array}{l}\text { (A) mycelium } \\
\text { status }\end{array}$ & 213.39 & 611.41 & 1 & 1 & 213.39 & 611.41 & 13.60 & 16.25 & 0.0942 & 0.004 \\
\hline (B) sucrose & 424.54 & 656 & 2 & - & 212.27 & 328 & 3.59 & 8.25 & 0.0772 & 0.061 \\
\hline $\begin{array}{l}\text { (C) sodium } \\
\text { nitrate }\end{array}$ & 835.73 & 682 & 2 & - & 417.87 & 341 & 7.06 & 4.62 & 0.0171 & 0.003 \\
\hline (D) $\mathrm{Mg} \mathrm{SO} 4$ & - & 460.58 & - & 2 & - & 230.29 & - & 6.12 & - & 0.0184 \\
\hline (E)Temperature & 745.21 & 444.18 & 2 & 2 & 372.60 & 222.09 & 6.26 & 5.90 & 0.0228 & 0.0203 \\
\hline (F) Agitation & 459.30 & 386.16 & 2 & 10 & 229.65 & 37.62 & 3.88 & 3.22 & 0.0664 & 0.0192 \\
\hline $\begin{array}{l}\text { Sourcmodel } \\
\text { (Significant } \\
\text { model) }\end{array}$ & 2794.6 & 1513.55 & 9 & 7 & 310.5 & 216.22 & 15.24 & 15.75 & 0.0145 & 0.0070 \\
\hline
\end{tabular}


The regression analysis revealed that the observed model errors are very low in both fungal species which indicated the accuracy of experimentation (Table 7) .The standard deviation values were 3.69 and 3.13 for A. niger \& S.silvatica with values of R-square 0.8551 and 0.8009 , respectively. Furthermore the predicted $\mathrm{R}$-squares of $0.6646 \& 0.6493$ were in reasonable agreement with adjusted $\mathrm{R}$ squares 0.6920 and 0.6615 in $A$. niger and $S$. silvatica, respectively. The adequate precision of 7.330 and 8.455 indicate an adequate signal for $\mathrm{Cr}^{+6}$ biosorption by $A$. niger and S. silvatica, respectively, as a ratio greater than four is desirable in Taguchi system (Prasad et al., 2005).

TABLE 7. The regression analysis values.

\begin{tabular}{|c|c|c|c|c|c|c|c|c|}
\hline $\begin{array}{c}\text { Fungal } \\
\text { species }\end{array}$ & Std.dev. & Mean & $\begin{array}{c}\text { Coefficient } \\
\text { variance }\end{array}$ & Precission & $\begin{array}{c}\text { R- } \\
\text { square }\end{array}$ & $\begin{array}{c}\text { Adj R- } \\
\text { square }\end{array}$ & $\begin{array}{c}\text { Pred.R- } \\
\text { square }\end{array}$ & $\begin{array}{c}\text { Adeq } \\
\text { precision }\end{array}$ \\
\hline A.niger & 3.69 & 16.20 & 47.50 & 3056.68 & 0.8551 & 0.6920 & 0.6646 & 7.330 \\
\hline S. silvatica & 3.13 & 13.24 & 46.31 & 1097.48 & 0.8009 & 0.6615 & 0.6493 & 8.455 \\
\hline
\end{tabular}

TABLE 8. The coefficient estimate with standard error.

\begin{tabular}{|c|c|c|c|c|c|c|}
\hline \multirow{2}{*}{ Variables } & \multicolumn{2}{|c|}{ Coefficient estimate } & \multicolumn{2}{|c|}{ Standard error } & \multicolumn{2}{|c|}{$\begin{array}{c}\text { Coefficient Indix } \\
(95 \%)\end{array}$} \\
\hline & A. niger & S. silvatica & A. niger & S. silvatica & A. niger & S. silvatica \\
\hline Intercept & 14.13 & 9.21 & 2.84 & 1.77 & 7.58 & 5.18 \\
\hline (A) & -5.41 & -7.42 & 2.84 & 1.84 & -11.98 & -11.52 \\
\hline $\mathrm{B}(1)$ & 8.43 & - & 1.09 & - & 15.77 & - \\
\hline $\mathrm{B}(2)$ & -3.16 & - & -9.27 & - & 2.95 & - \\
\hline $\mathrm{C}(1)$ & 0.41 & - & -7.41 & - & 8.23 & - \\
\hline $\mathrm{C}(2)$ & 9.07 & - & 1.84 & - & 16.30 & - \\
\hline $\mathrm{D}(1)$ & - & -1.77 & - & -6.35 & - & 2.81 \\
\hline $\mathrm{D}(2)$ & - & -5.24 & - & -9.81 & - & -0.66 \\
\hline $\mathrm{E}(1)$ & -8.78 & -7.04 & -15.35 & -11.61 & -2.21 & -2.46 \\
\hline $\mathrm{E}(1)$ & -0.58 & 3.93 & -6.81 & -0.65 & 5.65 & 8.51 \\
\hline $\mathrm{G}(1)$ & -7.51 & -3.64 & -13.75 & -8.21 & -1.28 & 0.94 \\
\hline $\mathrm{G}(2)$ & -0.46 & -3.04 & -2.85 & -7.61 & 9.76 & 1.54 \\
\hline
\end{tabular}

The estimate model coefficient and their associated statistics were reported in (Table 8).

Final equation in terms of coded factors:

Biosorbed $\mathrm{Cr}^{+6}$ by $($ A. niger $)=+14.13-5.41+8.43-3.16+0.41+9.07-8.78-0.58-$ 7.51-0.46

Biosorbed $\mathrm{Cr}^{+6}$ by $($ S. silvatica $)=+9.21-7.42-1.77-5.24-7.04+3.93-3.64-3.04$

The optimized predicted medium from the Taguchi designed for $\mathrm{Cr}^{+6}$ biosorption by A. niger \& S. silvatica was composed of: (A)Mycelium status (dead), (B) Sucrose $\left(15 \mathrm{gL}^{-1}\right)$, (C) $\mathrm{NaNO}_{3}\left(1.5 \mathrm{gL}^{-1}\right)$, (D) $\mathrm{MgSO}_{4} 7 \mathrm{H}_{2} \mathrm{O}\left(0.1 \mathrm{gL}^{-1}\right)$, (E)Temperature $\left(18^{\circ} \mathrm{C}\right)$, (F) $\mathrm{pH}(5),(\mathrm{G})$ Agitation (static), (H) Incubation period (5 days).

Egypt. J. Bot., 54, No. 1 (2014) 


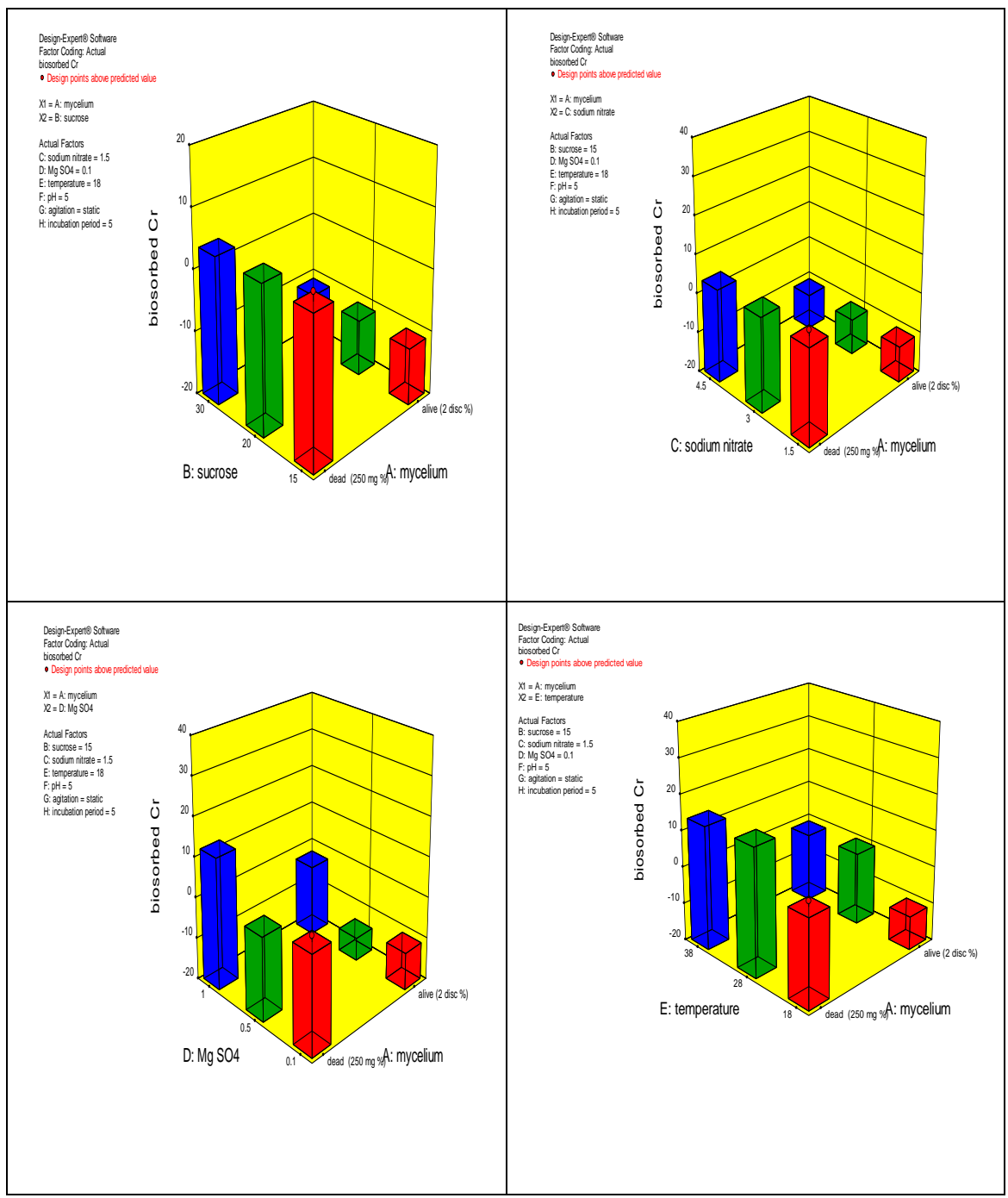

Fig. 1a. Variable interactions with the mycelium (dead \& alive) of S.silvatica in $\mathrm{Cr}^{+6}$ biosorption. 


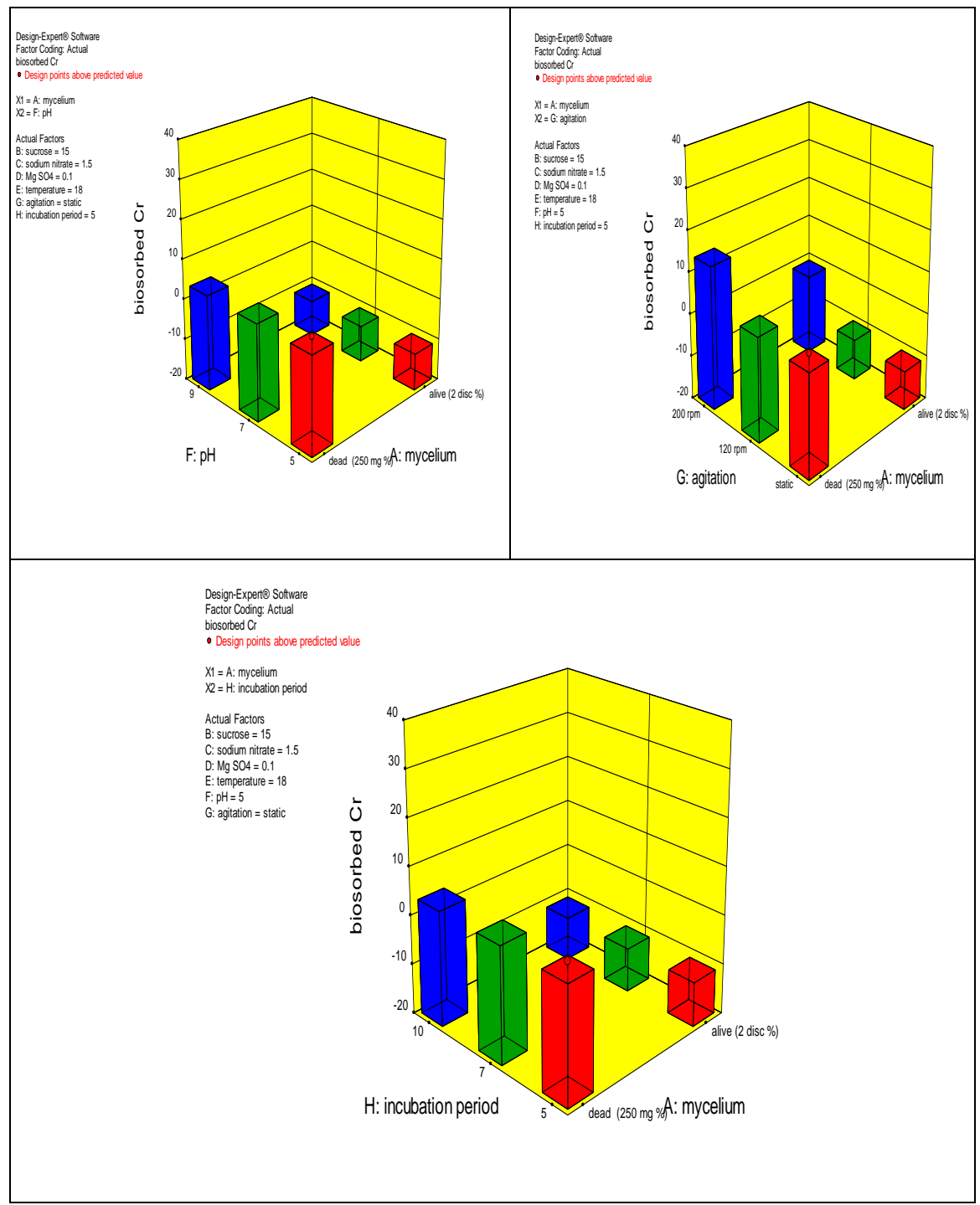

Fig. 1 b. Variable interactions with the mycelium (dead \& alive) of S.silvatica in $\mathrm{Cr}^{+6}$ biosorption. 


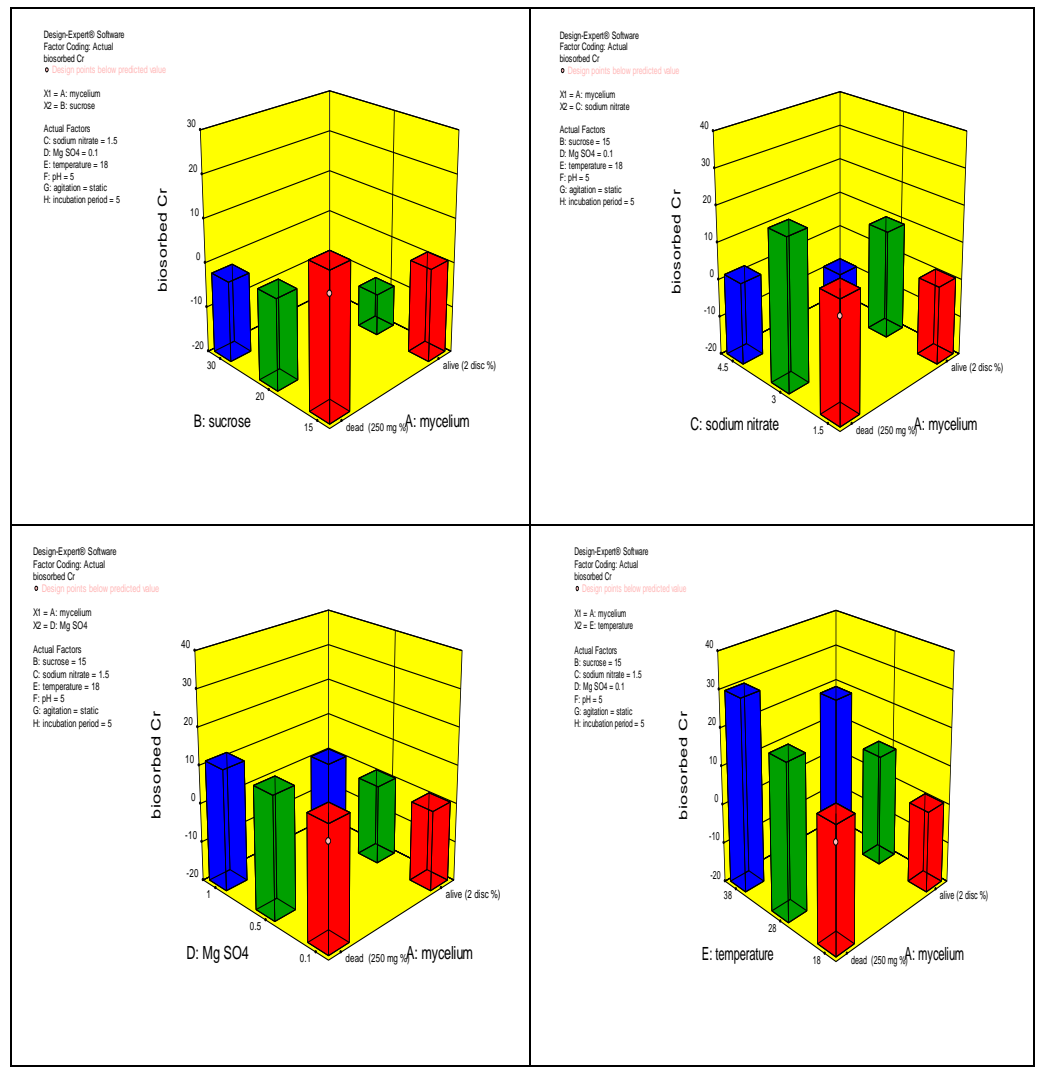

Fig. 2 a. Variable interactions with the mycelium (dead \& alive) of A.niger in $\mathrm{Cr}^{+6}$ biosorption. 


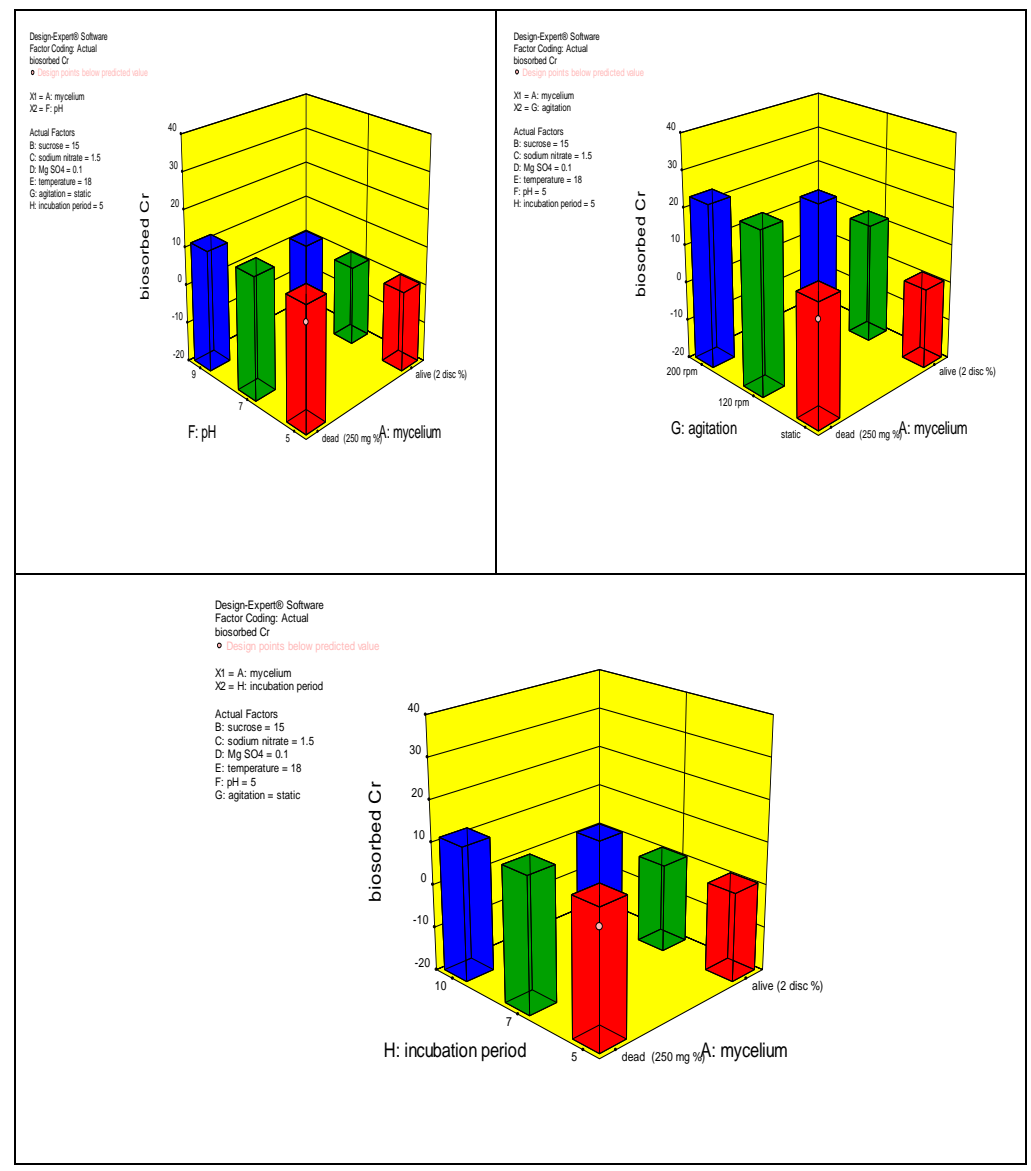

Fig. 2 b. Variable interactions with the mycelium (dead \& alive) of A.niger in $\mathrm{Cr}^{+6}$ biosorption

\section{References}

1. Anaemene, I. A. (2012) The use of Candida sp. In the biosorption of heavy metals from industrial effluent. European Journal of Experimental Biology, 3, 484-488.

2. Bartlett, R.J. and James, B. R. (1996) Chromium. In "Methods of Soil Analysis". D. L. Sparks (Ed.), Part3.SSSA, Madison, p. 683-701.

3. Dasu, V. V. and Panda, T. (2000) Optimization of microbiological parameters for enhanced griseofulvin production using response surface methodology. Bioprocess Engineering, 22, 45-49.

4. Doehlert, D. H. (1970) Uniform shell designs. Applied Statistics, 19, 231-239. 
5. Ferraz, A. I. and Teixera, J. A. (1999) The use of flocculating brewer's yeast for $\mathrm{Cr}(\mathrm{III})$ and $\mathrm{Pb}(\mathrm{II})$ removal from residual wastewater. Bioprocess and Biosystems Engineering, 21, 431 - 437.

6. Gadd, G. M. and White, C. (1989) Removal of thorium from simulated acid proc streams by fungal biomass. Journal of Chemical Technology \& Biotechnology, 33, $592-7$.

7. Ibrahim, M. and Shalaby, Z. (1991) Productivity Improvement for the Egyptian NationalEconomy, with emphasis on the Industrial Sector: Measurements and Assessment of Productivity in the Textiles, Fabrics and Leather Industries. National Research Institute, Egypt.

8. Kapoor, A. and Viraraghavan, T. (1998) Biosorption of heavy metals on Aspergillus niger: Effect of pretreatment. Bioresource Technology, 63,109-113.

9. Kapoor, A., Viraraghavan, T. and Cullimore, D. R. (1999) Removal of heavy metals using the fungus Aspergillus niger. Bioresource Technology, 70, 95-104.

10. Luef, E., Prey, T. and Kubicek, C. P. (1991) Biosorption of zinc by fungal mycelial wastes. Applied Microbiology Biotechnology, 34, 688-692.

11. Mclean, R. J. C., Campbell, A. M., Khu, P. T., Persaud, A. T., Bickerton, L.E. and Beau C. D. (1994) Repeated use of Bacillus subtilis cell walls for copper binding. World Journal of Microbiology and Biotechnology, 10, 472-474.

12. Prasad, K. K., Mohan, S. V., Rao, R. S., Pati, B. R. and Sarma, P. N. (2005) Laccase production by Pleurotus ostreatus 1804 Optimization of submerged culture conditions by Taguchi DOE methodology. Journal of Biochemical Engineering, 24,17-26.

13. Rao, C. R. N.; Iyengar, L. and Venkobachar, C. (1993) Sorption of copper (II) from aqueous phase by waste biomass. Journal of Environmental Engineering, 119, $369-377$.

14. Reddy, L. V. A., Wee, Y., Yun, J. and Ryu, H. (2008) Optimization of alkaline protease production by batch culture Bacillus sp. RKY3 through Plackett-Burman and response surface methodological approaches. Bioresource Technology, 99(7), 22422249.

15. Sharma, D. C. and Satyanarayana, T. (2006) A marked enhancement in the production of a highly alkaline and thermostable pectinase by Bacillus pumilus dcsr1 in submerged fermentation by using statistical methods. Bioresource Technology, 97, $727-733$

16. Singh, S.; Pradhan, S. and Rai, L. C. (1998) Comparative assessment of $\mathrm{Fe}^{3+}$ and $\mathrm{Cu}^{2+}$ biosorption by field and laboratory grown Microcystis. Process Biochemistry, 33, 495-504 
17. Spinti, M.; Zhuang, H. and Trujillo, E. M. (1995) Evaluation of immobilized biomass beads for removing of heavy metals from wastewaters. Water Environment Research, 67, $943-954$.

18. Sreeram, K. J. and Ramasami, T. (2003) Sustaining tanning process through conservation, recovery and better utilization of chromium. Resources, Conservation and Recycling, 81, 185-212.

19. Tharwat, N. A., Mostafa, A. H., Abdel-Rahman, T. M. A. and Ahmed, M. A. (2013) Biosorption of hexavalent chromium tannery water using some fungi isolated from tannery effluent. Egyptian J. Botany, (Under publication).

20. Ting, Y. P., Lawson, F. and Prince, I. G. (1991) Uptake of cadmium and zinc by the alga Chlorella vulgaris: II. Multi-ion situation. Biotechnology and Bioengineering, 37, 445-455.

21. Tobin, J. M. (2001) Fungal metal biosorption, In: "Fungi in Bioremediation", Gadd, pp. 424-444 G.M, Cambridge University Press, Cambridge, New York.

22. Volesky, B. (1990) Biosorption by fungal biomass .In: Biosorption of Heavy Metals Volesky, B. (Ed.),pp.140-171.CRC press,Florida.

23. Volesky, B. and Holan, Z. R. (1995) Biosorption of Heavy Metals - Review. Biotechnology Progress, 11, 235-250.

24. Volesky, B. and May-Philips, H. A. (1995) Biosorption of heavy metals by Saccharomyces cerevisiae. Applied Microbiology Biotechnology, 42, 797-806.

25. Yan, G. and Viraraghavan, T. (2000) Effect of pretreatment on the bioadsorption of heavy metals on Mucor rouxii. Water SA, 26, 119-123.

(Received 18/6/2013; accepted 26/8/2013) 
OPTIMIZATION OF BIOSORPTION CONDITIONS ...

التحكم فى الامتزاز الحيوى للكروم السداسى بواسطة الاغزال

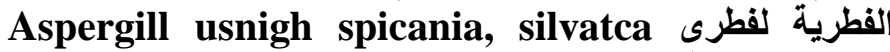

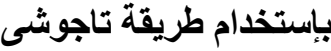

نجوى ثروت1 ، تهانى عبدالرحمن1 ، أمير مصطفى2 و مروة أحمد2

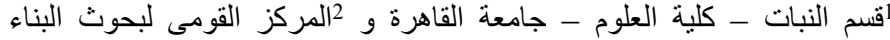

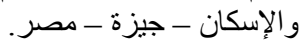

لتحقيق أقصى قدر من الكفاءة فى الامتصاص الحيوى تم تصميم ثمانية عشر تجربة

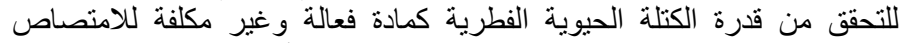

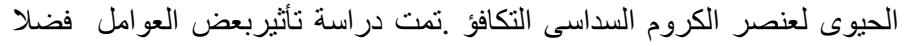

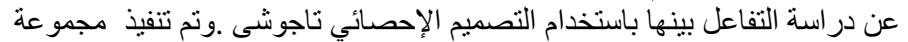

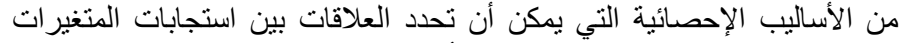

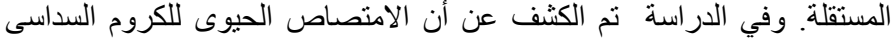

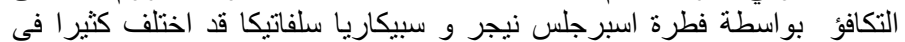

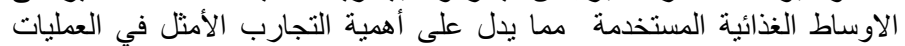

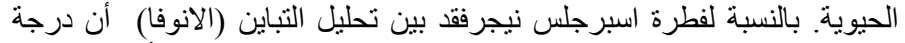

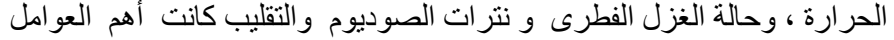

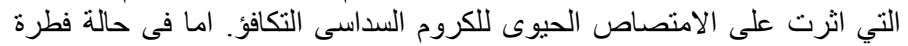

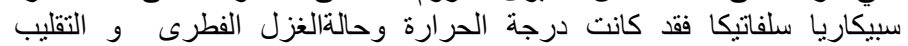

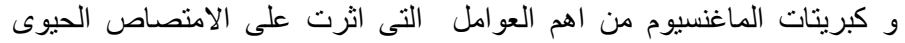

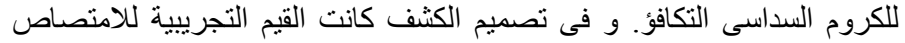

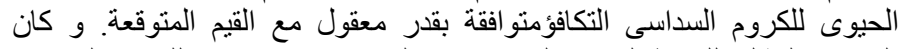

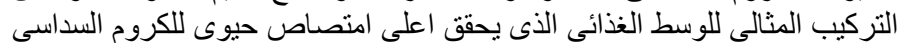

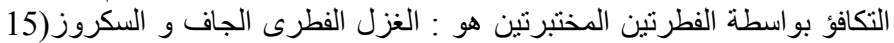

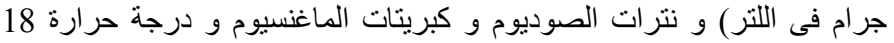
درجة مئوية و درجة حموضة 5 و الزر التر اعة الثابتة لمدة 5 ايام. 